floor pad of this area from neighbouring floor pads, and from columns supporting structures above, to ensure that this area will be mechanically quiet.

The east wing is a concrete frame structure with mullions at $5 \mathrm{ft} .4 \mathrm{in}$. intervals. It is predominantly a research and office block on three floors and has been designed so that all research rooms are on the west side of the block and all offices on the east side, thus economizing in electrical and mechanical services. Each lecturer will have a small office in which he can tutor students in groups of two or three. He may also have a research room conveniently situated opposite his office. The east wing also includes a class library, a common room, and a small lecture room which can be used for research seminars and occasional honours lectures. The flat roof of this wing has been strengthened at one end so that it can be used for experimental purposes.

The west wing houses all the teaching laboratories. The ground (podium) floor is given over to first - and secondyear laboratories, while the first floor houses all honours laboratories. Since the first-and second-year classes are by far the largest, this arrangement minimizes traffic on stairways and provides vibrationally the quietest conditions where most needed, that is, in the honours laboratories. The guiding principle governing the layout of the laboratories has been to prefer small laboratories of a size that can be comfortably supervised by one person. This also has the merit of providing greater flexibility in the general day-to-day use of these laboratories. In addition, each group of laboratories is provided with its own services and store rooms, together with a number of photographic dark rooms. The first floor also provides a number of tutorial rooms. where first- and secondyear tutorials in groups of 20-25 students each can be given.

The cost of the Building was approximately $£ 700,000$ provided by the University Grants Committee with a contribution from University funds.

The architect was Mr. E. D. Jefferiss Mathews of Messrs. J. Douglass Mathews and Partners, tha quantity surveyors Messrs. John Dansken and Purdie, the structural engineers Messrs. C. V. Blumfield and Partners, and the contractors Messrs. Alexander Hall and Son (Builders), Ltd., Aber. deen.

\title{
AN EARLY OCCUPATIONAL HEALTH SERVICE
}

\begin{abstract}
$\mathrm{T}$ HE remarkable work of Samuel Greg and Dr. P. Holland in establishing an occupational health service at Quarry Bank Mill, Cheshire, in the late eighteenth century has recently been described by Dr. R. Murray, medical adviser to the Trades Union Congress (Occupational Health, 16, No. 1; January/February 1964).

Quarry Bank Mill was built as a spinning mill in 1784 by Greg, who, by 1795, was employing his own family doctor, Dr. Holland, to provide medical care for the Company's apprentices for an annual fee of twelve guineas. Details of his work are recorded in two fully documented notebooks. The treatment was heroic and much of it consisted of purgatives - senna, calomel, rhubarb and ginger, jalap and salts. Clysters were frequently given; blisters, leeches and poultices were common. Coughs were treated with horehound and ipecac. The sick were usually given buttermilk or churn whey, though red wine, broth and even tea were sometimes prescribed. Itch was treated with sulphur, internally as well as extern. ally.
\end{abstract}

The policy of Samuel Greg in appointing Dr. Holland as his works physician was not entirely philanthropic. $\mathrm{He}$ said, in answer to a correspondent, "The terms in which we take them are ... (that) we keep them one month upon trial before (being) bound ... to ascertain their prob- able healthiness". At this time the Boards of Guardians were anxious to rid themselves of the rapidly rising population of children in poorhouses, and the system of "binding them apprentice", which had served well enough for 200 years, was used to ensure a cheap supply of labour for the developing textile industry. For a variety of reasons, many of these children were physically or mentally unfit for employment, and several employers found it worth while to employ a physician to discard those who were unlikely to make useful workers.

Nevertheless, in the case of Quarry Bank, the treatment was much more generous than elsewhere. Out of a total of 17,000 apprentices who passed through the mill, only five, apart from those under nine years, were not employed. There are several instances of children being kept for a year or more, seen regularly by Dr. Holland, and well fed in the apprentice house before being inden. tured. The details of the pre-employment examinations indicate the extent to which tuberculosis was a scourge of the times. Eighty per cent of the children who were labelled 'untealthy' were said to be 'delicate', to have inflammation of the eyes, enlarged glands or to be scrofulous. The fact that so many of them were ultimately able to be indentured says much for the philanthropy of Samuel Greg and the care of Dr. Holland.

\section{SEARCH FOR OIL IN AUSTRALIA}

T HE pursuit of the elusive oil-pools in Australia continues with undiminished vigour, and unfortunately the two latest reports* do little to enliven the rather depressing trend of ovents, at least from an economic point of view, recently chronicled (Nature, 201, 1080; 1964 ; and 200,123 ; 1963).

Publication No. 23 describes the exploratory borehole drilled as an off-structure stratigraphic test by the

* Commonwealth of Australia. Department of National Development. Bureau of Mineral Resources, Geology and Geophysics. Petroleum Search Subsidy Acts. Publication No. 23: Conorada Ooroonoo No. 1, Queensland, of Conorada Petroleum Corporation. Pp. 30+2 plates. Publication No. 42: O.D.N.L. Penola No. 1 Well, South Australia, of Oil Development N.L. Pp. Geophysics, 1963.)
Conorada Petroleum Corporation and known as "Conorada Ooroonoo No. 1, Queensland". The location borders the Diamantina River, about 58 miles south of Middleton, on Western Highway, western Queensland. As a stratigraphic test, this project might be judged successful, in that the log disclosed a complete section of the sedimentary rocks of the Great A.rtesian Basin down to and penetrating the granitic basement complex. Operations lasted barely one month and the well was abandoned as a dry hole at a total depth of $3,852 \mathrm{ft}$., the granite floor being met at $3,840 \mathrm{ft}$. Considerable problems attach to the age determination of the rocks constituting the Great Artesian Basin in this region. The possibility of finding 